\title{
Effectiveness of Video Assisted Teaching Module (VATM) on Knowledge, Attitude and Utilization of Voluntary Counseling Testing Center (VCTC) Service among the College Students in the Selected Colleges of Pondicherry
}

\author{
Felicia Chitra ${ }^{1}$, Kalavathi $\mathrm{K}^{2}$ and Manju Bala Dash ${ }^{3 *}$ \\ ${ }^{1}$ Department of Medical Surgical Nursing. Mother Theresa Post Graduate and Research Institute of Health Sciences, India \\ ${ }^{2}$ Department of Obstetrics and Gynecology, Annamalai University, India \\ ${ }^{3}$ Department of Obstetrics and Gynecology, Mother Theresa Post Graduate and Research Institute of Health Sciences, India
}

\begin{abstract}
Voluntary Consulting and Testing (VCT) is one of the important strategies planned and implemented to fight against the spread of HIV.
\end{abstract}

Objectives: To assess the existing knowledge, attitude and utilization of VCTC services among the college students.

Methodology: Quasi experimental study was conducted among 400 college students (200 in experimental and 200 in control group) from the selected colleges of Pondicherry. Pretest was given to both the groups and Video teaching was shown only to the experimental group students. Posttest was conducted after 8 days of pretest and at 1 month and at 3 month to assess the utilization of VTC.

Result and findings: The distribution of the demographic characteristics of college students shows that $58 \%$ and $53.5 \%$ of the students were in the age group of 19 to 20 years in the experimental and control group respectively. The mean pretest knowledge score of the college students was $19.6 \pm 5.17$ and $20.75 \pm 6.47$ whereas the posttest mean knowledge score is $29.44 \pm 4.36$ and $12.96 \pm 8.56$ in the experimental and Control group respectively. The pretest attitude score was $36.77 \pm 6.01$ and $39.78 \pm 5.66$ whereas the posttest mean attitude score is $45.93 \pm 6.32$ and $36.6 \pm$ 5.43 in the experimental and control group respectively.

Conclusion: Video teaching on VCTC has the impact on improvement in the knowledge, attitude and utilization of the VCT services.

Keywords: Video teaching; VCTC; Knowledge; Attitude; Utilization of VCTC; College student

\section{Introduction}

Acquired Immunodeficiency Syndrome (AIDS), is posing itself to be one of the most serious challenges to the global public health which is caused by Human Immune Deficiency Virus (HIV). Around 36.9 million people were living with HIV, with a global HIV prevalence of $0.8 \%$, towards the end of 2014 as per WHO global HIV statistics. There were around 2 million new HIV cases detected, out of which over 220,000 were children less than 15 years of age [1,2]. According to Government of India data highlights that $3.5 \%$ of all infections occur among children aged less than 15 years, whereas $83 \%$ occur in the age group of 15-49 years [3].

Further the biological, psychological and cognitive changes put the young generation to vulnerable. It is again, the age of impulsivity which is always accompanied by vulnerability. Peer pressure and media influence the changes in perception and practice of risk behaviors and acquisition of new emotional, cognitive and social skills [4].

The absence of any organized institution for imparting sex education, the young people incline to learn about sexual and reproductive health from unreliable and unauthenticated sources, which force them to have misconceptions about puberty, masturbation, sexual intercourse and the other forms like (anal, oral), reproductive health, STIs, etc. which further push them to be more susceptible to HIV/AIDS. Lack of knowledge about HIV/AIDS, inaccessibility to health services, lack of education and life skills and early marriage, all have increased the vulnerability of HIV/AIDS [5].
Regarding the scenario in Pondicherry, the estimated total prevalence rate of $\mathrm{HIV}$ is $0.15 \%$ with $0.18 \%$ among the males and $0.12 \%$ among the females. The total number of people living with HIV/AIDS in Pondicherry is 1,255 with 734 males and 521 females. The number of new infections is estimated to be 33 with 24 AIDS related deaths [6].

The HIV burden and its devastating impact on the human, particularly, the youth populations globally and nationally have gained attention of the World Health Organization and other Voluntary Organizations to take various steps to bring a halt to the epidemic. The United Nations has set the target of diagnosing $90 \%$ of all people suffer from HIV by 2020, which means making the PLWHA know their HIV status, towards attaining the goal of eradicating the HIV epidemic by 2030. Making every individual know his HIV status will be the ultimate strategy required to put the monster into the cage [7]. Voluntary HIV counseling and testing is the process by which the individual or the young person gets counseling which can empower him to make an informed

*Corresponding author: Manju Bala Dash, Department of Obstetrics and Gynecology, Mother Theresa Post Graduate and Research Institute of Health Sciences, India, Tel: +04132271200; E-mail: manju_narayan@rediffmail.com

Received June 27, 2018; Accepted July 02, 2018; Published July 09, 2018

Citation: Chitra F, Kalavathi K, Dash MB (2018) Effectiveness of Video Assisted Teaching Module (VATM) on Knowledge, Attitude and Utilization of Voluntary Counseling Testing Center (VCTC) Service among the College Students in the Selected Colleges of Pondicherry. J Health Educ Res Dev 6: 277. doi: 10.4172/23805439.1000277

Copyright: (c) 2018 Chitra F, et al. This is an open-access article distributed under the terms of the Creative Commons Attribution License, which permits unrestricted use, distribution, and reproduction in any medium, provided the original author and source are credited. 
Citation: Chitra F, Kalavathi K, Dash MB (2018) Effectiveness of Video Assisted Teaching Module (VATM) on Knowledge, Attitude and Utilization of Voluntary Counseling Testing Center (VCTC) Service among the College Students in the Selected Colleges of Pondicherry. J Health Educ Res Dev 6: 277. doi: 10.4172/2380-5439.1000277

Page 2 of 6

choice regarding getting tested for HIV. Stigma and fear of testing positive was the major obstacle in utilizing these VCT services. Apart from this, distance to the VCT center, lack of knowledge and attitude on VCT services, failing to perceive their risk of contracting HIV, fear of being isolated or discriminated, worries about confidentiality were the other reasons reported as the barriers towards utilization of the VCTs [8-10]. Only $25-30 \%$ of the people, living with HIV/AIDS, are aware of their HIV in India which is a greatest challenge in March towards the goal to end AIDS by 2030 [11].

Turkson et al. [12] had highlighted that the College students had some knowledge on VCT service but most of them were not aware of availability of VCT services [12].

Fikadie et al. [13] had reported that though college students were aware of VCT services and its availability, their utilization of VCT (i.e.) the testing for HIV was low. Ndwiga and Omwono (2014), also reported that there was high level of awareness about VCT among the college students, but with low utilization of VCT Services having only $52 \%$ tested [13]

Education and dissemination of health information is the most important and priority strategy to push the individuals to seek the health facilities to alleviate the myths and misconceptions about HIV/ AIDS and be better informed of where, when and how to access the Voluntary Counseling and Testing Centers. There are very many studies which spotlight the effectiveness of video-assisted teaching module in creating awareness and providing information to college students [14-17].

The investigator's personal association with the voluntary organization rendering services to people living with HIV/AIDS and understanding the enormous efforts that every citizen of India has to support the nation in its war against the deadly disease HIV/AIDS, Created interest to conduct the present study to enhance the utilization of ICTC services among the college students in the Union Territory of Pondicherry.

\section{Objectives of the study}

- To assess the existing knowledge and attitude regarding the VCTC services among the college students.

- To assess the existing utilization of VCTC services among the college students.

- To assess the effectiveness of VATM on the knowledge and attitude regarding VCTC services among the college students.

- To assess the effectiveness of intervention package on utilization of VCTC services among the college students.

\section{Hypotheses of the study}

There will be significant increase in the posttest knowledge and attitude scores regarding VCTC services among the college students in the experimental group than in the control group.

There will be significant enhancement in the utilization of ICTC/ VCTC services among the college students in the experimental group than in the control group.

\section{Methodology}

\section{Research design}

True-Experimental research design-pre and posttest with control group design was adopted to assess the effectiveness of intervention towards knowledge and attitude and utilization of VCTC services among the college students.

\section{Research settings}

The study was conducted in Arts, Science, Engineering and B.Ed. colleges in the union territory of Pondicherry. The colleges selected for the study are affiliated to Pondicherry university and were situated 0.1 $15 \mathrm{Km}$ away from the place of the investigator. The colleges had total strength of students from a minimum of 700 to a maximum of 2000 and above with many departments of Arts and Science, Engineering subjects with students enrolled from both rural and urban areas.

\section{Sample and sample size}

In the present study, 400 college students, 200 in each of experimental and control group were recruited.

\section{Sampling technique}

Sampling technique was done by five-stage cluster.

First stage: All the colleges under Pondicherry University were clustered region wise (Pondicherry, Karaikal, MAHE and Yanam). Puducherry was selected by convenience sampling technique.

Second stage: All the colleges in Puducherry, were clustered discipline wise (Arts \& Science, Engineering, B.Ed, Law, Agriculture, Poly technique etc.) and Arts and Science, Engineering, B.Ed colleges were selected.

Third stage: From the clusters (68) of Arts and Science, Engineering, B.Ed. colleges, 4 colleges was randomly selected using lottery method.

Fourth stage: 2 disciplines were selected randomly from each college.

Fifth stage: 50 students were selected using systematic sampling method from each of the selected discipline. Thus, 200 college students in the experimental group and 200 college students in the control group were recruited [18].

\section{Criteria for sample selection}

Inclusion criteria: College students;

- Both male and female.

- Both UG and PG.

- Both married and unmarried.

- Of arts, science, engineering or B.Ed. colleges.

- Who would willingly participate in the study?

- Who can read and write English or Tamil.

Exclusion criteria: College students;

-Who were differently abled particularly with hard of hearing.

-In medical, nursing and other paramedical courses.

Ethical consideration: Ethical clearance was obtained from the Institutional Human Ethical Committee of Rajah Muthiah Institute of Health Sciences for conducting the study. Permission from the individual college authorities and an informed consent from each of the participants were obtained for the study.

Description of the tool and scoring procedure: The final tool used in the present study consisted of the 4 sections as described below: 
Citation: Chitra F, Kalavathi K, Dash MB (2018) Effectiveness of Video Assisted Teaching Module (VATM) on Knowledge, Attitude and Utilization of Voluntary Counseling Testing Center (VCTC) Service among the College Students in the Selected Colleges of Pondicherry. J Health Educ Res Dev 6: 277. doi: 10.4172/2380-5439.1000277

Page 3 of 6

Section A: Assessed the socio-demographic variables like age, gender, marital status, family status, place of residence, religion, educational status and HIV/AIDS awareness program using 8 structured-questions.

\section{Scoring pattern}

For the socio-demographic variables, no score was allotted.

Section B: It was a structured-questionnaire to assess the knowledge regarding the VCTC services and consisted of 38 items. Of the 38 items, the first two items were basic information on VCTC services and those who had 'yes' answer for these items, proceeded further to answer the rest of the 36 items.

Scoring: All the correct answers were given a score of ' 1 ' and all the wrong answers were given a score of ' 0 '. The maximum score was 38 . The level of knowledge was classified as Table 1.

Section C: It was a 5-point Liker scale to measure the attitude of college students towards ICTC/VCTC services. There were a total of 12 statements of which 6 were positive and 6 were negative statements. The positive statements were rated on 5 points-Strongly Agree-5, Agree-4, Neutral-3, Disagree-2, and strongly disagree- 1 . The maximum score for the positive statement was 5 and the scoring was reversed for the negative statement. The total score was 60 . The obtained score was classified as below (Table 2).

Section D: It was a structured-questionnaire with 6 questions on utilization of ICTC/VCTC services or intention to utilize the ICTC/ VCTC services.

Scoring: The 6 items were analyzed by using the frequency and percentage.

\section{Description of the intervention}

The Video-Assisted Teaching Module (VATM) on HIV/AIDS was the intervention. The content of the VATM was prepared based on the literatures referred from books, journals, report articles, magazines, pamphlets, etc., regarding HIV/AIDS. Then, the content was organized under the following headings.

- Introduction,

- Definition of the HIV/AIDS,

- Mode of transmission of HIV/AIDS,

- Signs and symptoms,

- Diagnostic measures,

- Treatment of HIV/AIDS,

- Prevention of HIV

- Conclusion.

VATM duration was 28 minutes.

The content of VATM was given for content validity along with the tool, to various experts in the field of nursing and medicine. The content of the VATM was translated into the local language Tamil

\begin{tabular}{|c|c|c|}
\hline Level of Knowledge & Score & Percentage (\%) \\
\hline Adequate & $27-38$ & $>75 \%$ \\
\hline Average & $18-27$ & $50 \%-75 \%$ \\
\hline Poor & $0-18$ & $<50 \%$ \\
\hline \multicolumn{2}{|c|}{} \\
\hline
\end{tabular}

Table 1: Level of Knowledge.

\begin{tabular}{|c|c|c|}
\hline Level of Attitude & Score & Percentage (\%) \\
\hline Positive & $36-60$ & $>60 \%$ \\
\hline Neutral & $24-36$ & $40 \%-60 \%$ \\
\hline Negative & $0-24$ & $<40 \%$ \\
\hline
\end{tabular}

Table 2: Level of Attitude.

and was retranslated into English to determine the correctness of the translation and was also certified by the language experts. The VATM $\mathrm{CD}$ was also validated by the experts for its content. The reliability of the tool was established by using Cronbach's alpha method separately for the each section. The obtained values were.

Section B: Knowledge on ICTC/VCTC services-0.968.

Section C: Attitude towards ICTC/VCTC-0.919.

Section D: Utilization of ICTC / VCTC-0.912

\section{Data collection procedure}

- Permission from concerned authority was obtained.

- Prior to the data collection, written permission was obtained from the college authorities.

- Ethical clearance was obtained from the Institutional Human Ethical Clearance Committee.

Informed consent from each of the participants was taken prior to data collection.

Step 1: The tool for data collection was distributed to the students and was asked to fill in the self-administered questionnaire. The student took around 40-45 minutes to fill in the questionnaire.

Step 2: The video-session was arranged for the students in the experimental group alone which went on for around 25-30 minutes. The video-session was conducted for a group of 50 students at a time. The students were given the contact number of the investigator to clarify further doubts regarding the topic after the session.

Step 3: Posttest was conducted on the 8th day after the initial data collection and video-session. Once again, the self-administered questionnaire was distributed among the participants in both the experimental and the control group. The posttest data were collected from the students. Only 187 students in experimental and 194 students in control group completed the posttest.

Step 4: 15th day after the posttest-I, a reminder SMS was sent to the mobile of students in the experimental group to reinforce the importance of HIV test.

Step 5: One month from the date of posttest-I, the posttest-II for both experimental and control group was conducted by asking students to fill up the utilization form.

Step 6: Three months from the date of posttest-I, the posttest-III was conducted for both experimental and control group. Again the students were asked to fill in the utilization form only.

Step 7: The participants were thanked for their co-operation and the information pamphlet which contained the contents of the video session was distributed to the entire participant in the control group.

\section{Results and Findings}

The distribution of the demographic characteristics of college students in experimental and control group. In both, the experimental and control group $58 \%$ and $53.5 \%$ of the students were in the age group 
Citation: Chitra F, Kalavathi K, Dash MB (2018) Effectiveness of Video Assisted Teaching Module (VATM) on Knowledge, Attitude and Utilization of Voluntary Counseling Testing Center (VCTC) Service among the College Students in the Selected Colleges of Pondicherry. J Health Educ Res Dev 6: 277. doi: 10.4172/2380-5439.1000277

Page 4 of 6

of 19 to 20 years respectively. Regarding gender, $69 \%$ and $68 \%$ were female in the experimental and control group respectively. Regarding marital status, in both the experimental and control group most $(96.5 \%$ and $95.5 \%$ ) of the students were single. Regarding place of residence, in the experimental group, $67.5 \%$ of the students were from the urban area where as in the control group, $58 \%$ of them were from rural area. In relation to religion, $82 \%$ and $89 \%$ were Hindus in the experimental and control group respectively. Regarding family status, most $75 \%$ to $78 \%$ of the students in both groups were from nuclear families respectively. In both experimental and control groups, $80 \%$ to $86 \%$ of the students were undergraduates. In relation to participation in HIV session, $72.5 \%$ and $73.5 \%$ of the students in the experimental and control group respectively had not attended any awareness sessions on HIV/AIDS. The non-significant $\mathrm{p}$ value indicated that the socio-demographic variables wise distribution of students in both experimental and control group were similar except for the variable place of residence before the intervention (Table 3).

Comparison of pretest Mean knowledge on VCTC services among the college students in Experimental and control group highlights that out of the 400 students, only 9 students in the experimental group and 32 students in the control group had heard about VCTC services. The mean knowledge score of the college students in the experimental group was $19.6 \pm 5.17$ and in the control group was $20.75 \pm 6.47$. Whereas the posttest mean knowledge score indicates that out of the 381 students who complete posttest I, 186 in the experimental and 51 in the control group had answered that they had heard about VCTC services after the intervention. The posttest mean knowledge score regarding VCTC services is $29.44 \pm 4.36$ of the experimental group when compared to that of control group $12.96 \pm 8.56$ up (Tables 4-7).

Comparison of the pretest mean attitude score towards VCTC services among the college students in the experimental and control group shows that in the experimental group it was $36.77 \pm 6.01$ and in the control group, it was $39.78 \pm 5.66$. The ' $t$ ' test value was 1.39 with $\mathrm{P}=0.171$. Whereas the posttest mean attitude score in the experimental and control group is $45.93 \pm 6.32$ and $36.6 \pm 5.43$ respectively. The result showed that the attitude of the college students in the experimental group had increased when compared to that of control group. Thus, it was revealed that the intervention had influenced the attitude regarding VCTC among college students in experimental group positively (Table 3).

Utilization of ICTC/VCTC of the college students one month after the intervention. $73.26 \%$ answered positively and $19.79 \%$ answered negatively. Interestingly, $6.95 \%$ of the students had undergone the test in the experimental group. In the control group, $82.47 \%$ of the college students were not willing to undergo tested and only $17.01 \%$ expressed their willingness. However, there were no additions in the number of students who underwent the test for HIV.

Utilization of VCTC of the college students three month after the intervention, shows that $69.51 \%$ answered positively and $22.99 \%$ answered negatively which revealed an increase in the students who were not willing to get tested for HIV in the posttest III when compared to posttest I and II, for the reasons which are not clear as to why the students were not willing for HIV test. Interestingly, $7.49 \%$ of the students had undergone the test in the experimental group. In the control group, $81.44 \%$ of the college students were not willing to undergo test and only $18.04 \%$ expressed their willingness. However, there were no additions in the number of students who underwent the test for HIV.

\section{Discussion}

In the present study the result shows that the mean knowledge and attitude score was improved related to VCTC service and it is also observed that the utilization of VTC was improved among the experimental group students than control group. Interestingly, the number of students who had actually undergone the test for HIV had increased from none during the posttest-I to 13 students in the posttestII and to 14 students in the posttest III in the experimental group. Nevertheless, the number of students who had actually undergone the test for HIV had increased from 1 student to 3 students in the posttest II and remained the same in the posttest III in the control group. Thus, the intervention had categorically been effective in motivating about 14 $(7.49 \%)$ college students in the experimental group to get their blood tested.

\begin{tabular}{|c|c|c|c|c|c|c|c|c|}
\hline \multirow{2}{*}{ Variable } & \multirow{2}{*}{ Sub-variable } & \multicolumn{2}{|c|}{ Experimental Group $(n=200)$} & \multicolumn{2}{|c|}{ Control Group ( $n=200)$} & \multirow{2}{*}{ Chi-Square test } & \multirow{2}{*}{ df } & \multirow{2}{*}{$P$ value } \\
\hline & & No. & $\%$ & No. & $\%$ & & & \\
\hline \multirow{4}{*}{ Age (in years) } & $17-18$ & 34 & 17 & 47 & 23.5 & \multirow{4}{*}{2.738} & \multirow{4}{*}{3} & \multirow{4}{*}{0.434 (NS) } \\
\hline & $19-20$ & 116 & 58 & 107 & 53.5 & & & \\
\hline & $21-22$ & 32 & 16 & 31 & 15.5 & & & \\
\hline & $22-23$ & 18 & 9 & 15 & 7.5 & & & \\
\hline \multirow{2}{*}{ Gender } & Male & 62 & 31 & 64 & 32 & \multirow{2}{*}{0.046} & \multirow{2}{*}{1} & \multirow{2}{*}{0.83 (NS) } \\
\hline & Female & 138 & 69 & 136 & 68 & & & \\
\hline \multirow{2}{*}{ Marital status } & Single & 193 & 96.5 & 191 & 95.5 & \multirow{2}{*}{0.26} & \multirow{2}{*}{1} & \multirow{2}{*}{0.61 (NS) } \\
\hline & Married & 7 & 3.5 & 9 & 4.5 & & & \\
\hline \multirow{2}{*}{ Place of residence } & Rural & 65 & 31.5 & 116 & 58 & \multirow{2}{*}{26.247} & \multirow{2}{*}{1} & \multirow{2}{*}{$0(\mathrm{~S})$} \\
\hline & Urban & 135 & 67.5 & 84 & 42 & & & \\
\hline \multirow{3}{*}{ Religion } & Hindu & 29 & 14.5 & 19 & 9.5 & \multirow{3}{*}{4.256} & \multirow{3}{*}{2} & \multirow{3}{*}{0.119 (NS) } \\
\hline & Muslim & 7 & 2 & 3 & 1.5 & & & \\
\hline & Christian & 16 & 82 & 178 & 89 & & & \\
\hline \multirow{2}{*}{ Family status } & Joint & 44 & 22 & 50 & 25 & \multirow{2}{*}{0.501} & \multirow{2}{*}{1} & \multirow{2}{*}{0.479 (NS) } \\
\hline & Nuclear & 156 & 78 & 150 & 75 & & & \\
\hline \multirow{2}{*}{ Educational status } & Under graduate & 172 & 86 & 160 & 80 & \multirow{2}{*}{2.551} & \multirow{2}{*}{1} & 011 (NS) \\
\hline & Post graduate & 28 & 14 & 40 & 20 & & & 0.11 (NS) \\
\hline HVVAIRS purronece cescion & Attended & 55 & 27.5 & 53 & 26.5 & 005 & 1 & $082 ?(\mathrm{NS})$ \\
\hline HIVIAIDS awareness session participatio & Not attended & 145 & 72.5 & 147 & 73.5 & 0.051 & 1 & 0.822 (NS) \\
\hline
\end{tabular}

Table 3: Socio-Demographic Variable of the College Students in Both Experimental and Control Group (N=400). 
Citation: Chitra F, Kalavathi K, Dash MB (2018) Effectiveness of Video Assisted Teaching Module (VATM) on Knowledge, Attitude and Utilization of Voluntary Counseling Testing Center (VCTC) Service among the College Students in the Selected Colleges of Pondicherry. J Health Educ Res Dev 6: 277. doi: 10.4172/2380-5439.1000277

Page 5 of 6

\begin{tabular}{|c|c|c|c|c|c|c|c|c|c|}
\hline \multirow{2}{*}{\multicolumn{2}{|c|}{ Item }} & \multicolumn{3}{|c|}{ Experimental group $(n=200)$} & \multicolumn{3}{|c|}{ Control group $(n=200)$} & \multirow{3}{*}{$\begin{array}{l}\text { 't' test } \\
0.461\end{array}$} & \multirow{3}{*}{$\begin{array}{c}\text { P value } \\
0.647\end{array}$} \\
\hline & & No. & Mean & S.D & No. & Mean & S.D & & \\
\hline \multirow{2}{*}{ Pretest Knowledge Regarding VCTC services } & Heard & 9 & 19.6 & 5.17 & 32 & 20.75 & 6.47 & & \\
\hline & Not heard & 191 & - & - & 168 & - & - & - & - \\
\hline Posttest & Heard & 187 & 29.44 & 4.86 & 51 & 12.96 & 8.56 & 17.82 & 0.001 \\
\hline Knowledge Regarding VCTC services & Not Heard & - & - & - & 143 & - & - & - & - \\
\hline
\end{tabular}

Table 4: Comparison of Mean Pretest and Posttest Knowledge Score Regarding VCTC Services among the College Students in the Experimental and Control Group $(\mathrm{N}=400)$.

\begin{tabular}{|c|c|c|c|c|c|c|c|c|c|}
\hline \multirow{2}{*}{\multicolumn{2}{|c|}{ Item }} & \multicolumn{3}{|c|}{ Experimental group $(n=200)$} & \multicolumn{3}{|c|}{ Control group $(n=200)$} & \multirow{2}{*}{ 't' test } & \multirow{2}{*}{$p$ value } \\
\hline & & No. & Mean & S.D & No. & Mean & S.D & & \\
\hline \multirow{3}{*}{ Pretest Attitude regarding VCTC services } & \multirow{2}{*}{ Heard } & \multirow{2}{*}{9} & \multirow{2}{*}{36.77} & \multirow{2}{*}{6.01} & \multirow{2}{*}{32} & \multirow{2}{*}{39.78} & \multirow{2}{*}{5.66} & \multirow{2}{*}{1.39} & 0.171 \\
\hline & & & & & & & & & (NS) \\
\hline & Not Heard & 191 & - & - & 168 & - & - & - & - \\
\hline Posttest & \multirow{2}{*}{ Heard } & \multirow{2}{*}{187} & \multirow{2}{*}{45.93} & \multirow{2}{*}{6.32} & \multirow{2}{*}{51} & \multirow{2}{*}{36.6} & \multirow{2}{*}{5.43} & \multirow{2}{*}{10.04} & \multirow{2}{*}{$0.001(\mathrm{~S})$} \\
\hline Attitude regarding VCTC services & & & & & & & & & \\
\hline & Not Heard & - & - & - & 143 & - & - & - & - \\
\hline
\end{tabular}

Table 5: Comparison of the Pretest and Posttest Mean Attitude Score towards VCTC Services among the College Students in the Experimental and Control Group (N=200).

\begin{tabular}{|c|c|c|c|c|c|c|c|}
\hline \multirow{2}{*}{ Items } & \multirow{2}{*}{ Sub-variables } & \multicolumn{3}{|c|}{ Experimental Group $(n=200)$} & \multicolumn{3}{|c|}{ Control Group $(n=200)$} \\
\hline & & $\mathbf{N}$ & No. & $\%$ & $\mathbf{N}$ & No. & $\%$ \\
\hline \multirow{5}{*}{$\begin{array}{c}\text { Reason for } \\
\text { willingness to get } \\
\text { tested }\end{array}$} & To Know HIV status before marriage & \multirow{5}{*}{51} & 16 & 31.37 & \multirow{5}{*}{31} & 10 & 32.25 \\
\hline & Recognize HIV is a serious problem & & 4 & 7.84 & & 0 & 0 \\
\hline & Risk behavior & & 1 & 1.96 & & 1 & 3.22 \\
\hline & To protect myself & & 4 & 7.84 & & 14 & 45.16 \\
\hline & To know my zero status & & 26 & 50.98 & & 6 & 19.35 \\
\hline \multirow{5}{*}{$\begin{array}{l}\text { If yes, when } \\
\text { wanted to get } \\
\text { tested }\end{array}$} & Any time & \multirow{5}{*}{51} & 29 & 56.86 & \multirow{5}{*}{31} & 16 & 53.33 \\
\hline & If arranged in college & & 2 & 3.92 & & 3 & 10 \\
\hline & Today & & 2 & 3.92 & & 1 & 3.33 \\
\hline & Before marriage & & 16 & 31.37 & & 6 & 20 \\
\hline & After my studies & & 2 & 3.92 & & 4 & 13.33 \\
\hline \multirow{6}{*}{$\begin{array}{l}\text { Reason for not } \\
\text { willing (Barrier) }\end{array}$} & Lack of knowledge & \multirow{6}{*}{149} & 60 & 40.26 & \multirow{6}{*}{169} & 24 & 14.04 \\
\hline & Afraid of discovering HIV status & & 15 & 10.06 & & 9 & 5.26 \\
\hline & Fear of being isolated & & 2 & 1.34 & & 2 & 1.17 \\
\hline & VCT only meant for sexually active & & 1 & 0.67 & & 5 & 2.92 \\
\hline & Denial of vulnerability & & 67 & 44.97 & & 116 & 68.63 \\
\hline & Afraid of HIV blood test & & 4 & 2.68 & & 15 & 8.77 \\
\hline
\end{tabular}

Table 6: Comparison of Pretest Reasons Regarding Utilization and Non- Utilization of ICTC/VCTC Services among the College Students in the Experimental and Control Group (N=400).

\begin{tabular}{|c|c|c|c|c|c|c|c|}
\hline \multirow{2}{*}{ Items } & \multirow{2}{*}{ Sub-variables } & \multicolumn{3}{|c|}{ Experimental Group ( $n=187$ ) } & \multicolumn{3}{|c|}{ Control Group $(n=194)$} \\
\hline & & $\mathbf{N}$ & No. & $\%$ & $\mathbf{N}$ & No. & $\%$ \\
\hline \multirow{5}{*}{ Reason for willingness to get tested } & To Know HIV status before marriage & \multirow{5}{*}{128} & 31 & 24.22 & \multirow{5}{*}{34} & 9 & 26.47 \\
\hline & Recognise HIV is a serious problem & & 8 & 6.25 & & 1 & 2.94 \\
\hline & Risk behaviour & & 5 & 3.91 & & 1 & 2.94 \\
\hline & To protect myself & & 21 & 16.41 & & 15 & 44.12 \\
\hline & To know my sero status & & 63 & 49.22 & & 8 & 23.53 \\
\hline \multirow{5}{*}{ If yes, when wanted to get tested } & Any time & \multirow{5}{*}{128} & 75 & 58.59 & \multirow{5}{*}{34} & 19 & 55.88 \\
\hline & If arranged in college & & 9 & 7.03 & & 2 & 5.88 \\
\hline & Today & & 7 & 5.47 & & 1 & 2.94 \\
\hline & Before marriage & & 29 & 22.66 & & 7 & 20.59 \\
\hline & After my studies & & 8 & 6.25 & & 5 & 14.7 \\
\hline \multirow{6}{*}{ Reason for not willing (Barrier) } & Lack of knowledge & \multirow{6}{*}{59} & 16 & 27.11 & \multirow{6}{*}{160} & 23 & 14.38 \\
\hline & Afraid of discovering HIV status & & 7 & 11.86 & & 9 & 5.63 \\
\hline & Fear of being isolated & & 1 & 1.69 & & 2 & 1.25 \\
\hline & VCT only meant for sexually active & & 0 & 0 & & 5 & 3.12 \\
\hline & Denial of vulnerability & & 34 & 57.63 & & 109 & 68.13 \\
\hline & Afraid of HIV blood test & & 1 & 1.69 & & 12 & 7.5 \\
\hline
\end{tabular}

Table 7: Comparison of the Post Intervention Reasons Regarding Utilization and Non-Utilization of ICTC/VCTC services of the College Students in the Experimental and Control Group $(\mathrm{N}=381)$. 
Citation: Chitra F, Kalavathi K, Dash MB (2018) Effectiveness of Video Assisted Teaching Module (VATM) on Knowledge, Attitude and Utilization of Voluntary Counseling Testing Center (VCTC) Service among the College Students in the Selected Colleges of Pondicherry. J Health Educ Res Dev 6: 277. doi: 10.4172/2380-5439.1000277

Page 6 of 6

The above finding is similar to the study conducted by Kebebew [19] where it is reported that there was a significantly high knowledge among the intervention group [19]. Further the study result supported by a study conducted by Thato et al. [20] using pretest, posttest nonequivalent control group design with 2 more follow up on "A brief, peer led HIV prevention program for college students in Bangkok Thailand". The study revealed that a Brief, Peer Led HIV Prevention Program significantly increased knowledge of preventive behaviors $(\beta=2.67, P<0.000)$, motivated participants to have a better attitude toward preventive behaviors $(\beta=5.26, \mathrm{P}<0.000)$, better subjective norms $(\beta=1.54, \mathrm{P}<0.000)$, and greater intentions to practice preventive behavior $(\beta=1.38, \mathrm{P}<0.000)$. The program also significantly decreased perceived difficulty of AIDS/STIs preventive behaviors $(\beta=2.38$, $\mathrm{P}<0.000)$ and increased perceived effectiveness at AIDS/STIs preventive behavior $(\beta=3.03, \mathrm{P}<0.000)$.

It was also supported to the study result of Gao et al. [21] conducted a study on "effectiveness of school based education on HIV/AIDS knowledge, attitude and behavior among 1,500 secondary school students in Wuhan, China". The study result showed that after the intervention all of the students had significant improvement in knowledge and attitude regarding HIV/AIDS, indicating the effect of educational program. Adeomi et al. [22] conducted an interventionstudy (quasi experimental type) to evaluate the effectiveness of peer education in improving HIV knowledge, attitude and preventive practices among 400 students (200 to the study group and 200 to the control group). The study showed that the peer education was effective in improving knowledge, attitude, and some preventive practices towards HIV/AIDS among in-school adolescents.

\section{Conclusion}

The VATM had significant in improving the knowledge, attitude and utilization of VCTC services among college students in the experimental group.

\section{Limitations}

The limitations recognized in the present study were:

- The data collected was based only on the response of the college students and not cross verified.

- Some students might have accessed the VCTC services and may not like to reveal it which interference in the utilization outcome.

- The tool used for data collection was not a standardized tool but constructed by the researcher.

- Utilization was assessed in 1 month and 3 months interval only.

\section{Recommendations}

- ICTC/VCTC services may be initiated in every college/ educational institutional and universities to enable availability and accessibility to the services.

- Education and awareness program regarding utilization may be arranged regularly in the educational institution.
- The government should emphasis the educational institutions to establish the cell for HIV counseling and testing services in the colleges.

\section{References}

1. UNAIDS (2015) How AIDS changed everything.

2. Reichenbach L, Roseman M (2011) Reproductive health and human rights: the way forward. University of Pennsylvania Press.

3. UNICEF (2015) Adolescents and young people.

4. Mulye TP, Park MJ, Nelson CD, Adams SH, Irwin CE, et al. (2009) Trends in Adolescent and Young Adult Health in the United States. J Adol Health 45: 8-24

5. WHO (2002) Increasing Access to HIV testing and counseling

6. NACO (2014) Fact Sheet 2013-2014

7. UNAIDS (2014) Fact Sheet.

8. National Health Profile (2011) Demographic Indicators.

9. NRHM (2014) Strategy Handbook.

10. Sisay S, Erku W, Medhin G, Woldeyohannes D (2014) Perception of High School Students on risk for acquiring HIV and utilization of Voluntary Counseling and Testing (VCT) service for HIV in Debre-berhan Town, Ethiopia: a quantitative cross-sectional study. BMC Res Not 7: 518.

11. Times of New India (2014) Four states in south make up $50 \%$ HIV cases.

12. Turkson $O$ (2015) Hierarchical Multiple Regression Modelling on Predictors of Behaviourand Sexual Practices at Takoradi Polytechnic, Ghana. Global J Health Sci 7: 200.

13. Fikadie G, Bedimo M, Alamrew Z (2014) Prevalence of Voluntary Counseling and Testing Utilization and Its Associated Factors among Bahirdar University Students. Adv Prev Med, pp: 1-9.

14. Nwozichi N (2015) Effect of video-based teaching module on knowledge about testicular cancer and testicular self-examination. Archiv Med Health Sci 3: 215-226.

15. Nair MK, Paul MK, Leena ML, Thankachi Y, George B, et al. (2012) Effectiveness of a reproductive sexual health education package among school going adolescents. Ind J Pediat 79: 64-68.

16. Okanlawon FA, Asuzu MC (2011) Effect of peer education intervention on secondary school adolescents' reproductive health knowledge in Saki, Nigeria. Afri J Med Med Sci 40: 353-360.

17. Rajesh S, Swamy AA (2014) Effectiveness of video assisted teaching programme on knowledge regarding non pharmacological pain relieving intervention for children among staff nurses in selected hospital. Asi J Multidiscipl Stud.

18. Polit DF, Hungler BP (1995) Nursing Research, Principles and Methods. JA Lippincott, Philadelphia, USA.

19. Kebebew $T$ (2007) Does distributing pamphlet make a difference in knowledge and attitude towards VCT among high school students.

20. Thato R, Penrose J (2013) A brief, peer-led HIV prevention program for college students in Bangkok, Thailand. J Pediat Adol Gynecol 26: 58-65.

21. Gao X, Wu Y, Zhang Y, Zhang N, Tang J, et al. (2012) Effectiveness of schoolbased education on HIVIAIDS knowledge, attitude, and behavior among secondary school students in Wuhan, China. PLoS ONE 7: e44881.

22. Adeomi AA, Adeoye OA, Asekun-Olarinmoye EO, Abodunrin OL, OlugbengaBello Al, et al. (2014) Evaluation of the Effectiveness of Peer Education in Improving HIV Knowledge, Attitude, and Sexual Behaviours among In-School Adolescents in Osun State, Nigeria. AIDS Res Treat 2014: 1-10. 